Cakrawala Dini: Jurnal Pendidikan Anak Usia Dini | p-ISSN 2087-|3177 | e-ISSN 2621-8321

Vol. 12. No.I Mei 2021 | Hal 7-18

\title{
PENERAPAN PERMAINAN BAHASA GUESSING GAMES BERBASIS POWERPOINT DALAM MENINGKATKAN KETERAMPILAN BERBICARA ANAK USIA DINI
}

\author{
Gita Vallenti Wibowo ${ }^{1}$, Suyadi ${ }^{2}$ \\ ${ }^{1,2}$ Universitas Islam Negeri Sunan Kalijaga Yogyakarta
}

\begin{abstract}
The motivation of this research is that some problems in children's speaking skills are not getting enough attention in several schools. Therefore, this study intends to describe how the application of PowerPoint-based guessing games in improving children's speaking skills in Group B of Thoyyibah Kindergarten in Bandar Lampung. This research used a qualitative descriptive method and a case study design. The research results describe the learning activity process with the application of powerpoint based guessing games in improving early childhood speaking skills consisting of 3 stages, namely planning, implementing, and evaluating/assessing. Children's speaking skills can be stimulated and developed well and significantly through the application of language games based on powerpoint guessing games, this can be seen in the child's pronunciation aspect develops well when the child is able to answer guesses given by the teacher and without directly the aspect of developing children's vocabulary increases and when the child retelling it shows that the sentence formation aspects have developed well. However, there are still some factors that limit the application of these games, namely the limited facilities in the form of computers / laptops, thereby reducing the learning atmosphere. In this case, educators overcome this by inviting children to take turns seeing the game.
\end{abstract}

Keyword: Language games, guessing games, powerpoint, speaking skills, early childhood.

\begin{abstract}
Abstrak: Motivasi dari penelitian ini adalah beberapa permasalahan pada keterampilan berbicara anak yang kurang mendapat perhatian di beberapa sekolah. Maka dari itu, penelitian ini bermaksud untuk menguraikan bagaimana penerapan permainan guessing games berbasis Powerpoint dalam meningkatkan keterampilan berbicara anak di Kelompok B Taman Kanak-kanak Thoyyibah di Bandar Lampung. Riset ini memakai metode deskriptif kualitatif serta desain studi kasus. Hasil penelitian memaparkan terkait proses kegiatan pembelajaran dengan penerapan permainan bahasa guessing games berbasis powerpoint dalam meningkatkan keterampilan berbicara anak usia dini terdiri dari 3 tahapan, yakni perencanaan, pelaksanaan, dan evaluasi/penilaian. Keterampilan berbicara anak dapat terstimulus dan berkembang dengan baik serta siginifikan melalui penerapan permainan bahasa guessing games berbasis powerpoint, hal ini tampak pada aspek pengucapan anak berkembang dengan baik ketika anak mampu menjawab tebakan yang diberikan guru dan tanpa secara langsung aspek pengembangan kosakata anak bertambah dan ketika anak bercerita kembali terlihat aspek pembentukkan kalimat sudah berkembang baik. Tetapi, masih terdapat sebagian faktor yang membatasai penerapan permainan tersebut yaitu keterbatasan fasilitas berupa computer/laptop sehingga mengurangi suasana belajar. Dalam hal ini pendidik mengatasinya dengan mengajak anak untuk melihat permainan secara bergantian.
\end{abstract}

Kata Kunci: Permainan bahasa, guessing games, powerpoint, keterampilan berbicara, anak usia dini

\footnotetext{
' Universitas Islam Negeri Sunan Kalijaga Yogyakarta, Email: 19204030056回student.uin-suka.ac.id

${ }^{2}$ Universitas Islam Negeri Sunan Kalijaga Yogyakarta, Email: suyadi国uin-suka.ac.id
} 


\section{PENDAHULUAN}

Pendidikan anak usia dini adalah suatu usaha pembinaan bagi anak-anak sejak lahir hingga usia delapan tahun. Rangsangan pendidikan yang diberikan pada usia ini dirancang untuk membantu anak dalam tumbuh dan kembangnya (McCoy et al., 2017, hlm. 475; SingerBrodowski et al., 2019, hlm. 494). Perkembangan bahasa adalah aspek perkembangan yang menjadi sasaran pembelajaran. Perkembangan bahasa anak merupakan keterampilan yang dapat berkomunikasi dengan orang lain (Taufiqurrahman \& Suyadi, 2016, hlm. 160). Perkembangan bahasa pada anak takkan lepas dari kemampuan berbahasa yakni mencakup keterampilan anak menyimak, keterampilan anak berbicara, keterampilan anak membaca serta keterampilan anak menulis (Syarif, 2016, hlm. 3).

Keterampilan mendengarkan adalah suatu proses yang melibatkan mendengarkan simbol yang diucapkan atau rangkaian simbol untuk memperoleh informasi atau berita dari pembicara (Nurzaman et al., 2020, hlm. 135), keterampilan membaca adalah proses yang menghubungkan serangkaian simbol dan kemudian mereka terdengar melalui bahasa lisan (Dhear et al., 2020, hlm. 115), keterampilan berbicara merupakan suatu proses yang didalamnya terdapat suatu bentuk komunikasi verbal yang bertujuan untuk menyampaikan sesuatu (Ruiyat et al., 2019, hlm. 519), dan keterampilan menulis adalah kegiatan berinteraksi dengan orang lain melalui simbol yang dapat dimengerti (Kurnia \& Solfiah, 2018, hlm. 344).

Perkembangan bahasa yang memegang peranan penting dalam upaya membentuk generasi penerus bangsa dengan kreativitas, warisan budaya, kecerdasan dan jiwa kritis adalah keterampilan berbicara anak. Dengan memiliki keterampilan berbicara, anak akan dapat mengekpresikan, mengungkapkan dan menyampaikan sebuah gagasan, pemikiran, konsep dan kepuasan batinnya terhadap orang lain dengan cara mengandalkan keterampilan berbicara yang dapat dipahami orang lain. Keterampilan berbicara anak diharuskan dilatih sejak usia dini agar anak dapat menemukan pengalaman dan menambah pengetahuan serta mengembangkan bahasanya (Kurnia, 2019, hlm. 2; Triyaningsih, 2016).

Namun faktanya keterampilan berbicara pada anak usia dini masih kurang mendapat perhatian. Berdasarkan hasil pra studi yang dilaksanakan oleh peneliti di Taman Kanak-kanak Thoyyibah Bandar Lampung keterampilan berbicara anak masih rendah. Ini bisa dilihat selama proses pembelajaran. Beberapa anak masih terdiam ketika diberi pertanyaan oleh pendidik dan belum bisa mengekspresikan ide atau gagasan dengan berani. Selain itu, pada beberapa penelitian sebelumnya ditemukan bahwa sebagian besar $(73 \%)$ siswa masih kurang dalam keterampilan berbicara (Shofa \& Suparno, 2014, hlm. 211) seperti kosakata yang masih sedikit, berbicara anak yang masih belum lancar baik itu dalam ketepatan pengucapan huruf vocal atau konsonan yang masih kurang jelas juga pilihan kata anak yang kurang bervaisasi (Ayuandia et al., 2017, hlm. 34).

Hal ini disebabkan oleh berbagai faktor, yakni pengetahuan anak yang masih kurang dimana anak belum dapat mengenali huruf, angka, dan warna dengan baik (Siregar \& Hazizah, 2019, hlm. 24), kurangnya bimbingan dimana dalam model pengajaran bahasa masih belum optimal, serta lingkungan di sekitar anak seperti anak terbiasa bermain sendiri (Puspita et al., 2019, hlm. 154). Berangkat dari permasalahan di atas, untuk membantu anak dalam meningkatkan keterampilan berbicara, hal ini dapat distimulasi melalui pembelajaran yang dikemas dalam bentuk permainan bahasa guessing games berbasis powerpoint. Ada banyak alasan menggunakan permainan 
untuk meningkatkan keterampilan berbicara. Permainan ini memberikan kesempatan kepada anak-anak, mereka dapat menggunakan bahasa lisan yang dikemas dalam bahasa yang menarik, namun akan membangkitkan semangat dan minat belajar mereka. Harapannya anak pemalu atau lambat dapat menunjukkan kemampuannya dan menemukan anak yang aktif percaya diri dalam komunikasi verbal (Hasanah, 2019, hlm. 23; Nestor \& Mose, 2018, hlm. 250; Wasik \& Jacobi-Vessels, 2017, hlm. 772).

Gordon Lewis dan Bedson menjelaskan bahwa salah satu jenis permainan bahasa yang mampu meningkatkan keterampilan berbicara anak adalah guessing games, yaitu permainan menebak yang tujuan utamanya adalah menebak jawaban suatu pertanyaan (Usman, 2015, hlm. 95-96). Dalam hal ini banyak penelitian yang telah menerapkan permainan bahasa guessing game atau permainan menebak dalam meningkatkan kemampuan berbahasa atau keterampilan berbicara anak. Diantaranya penelitian yang dilakukan oleh (Budiarti \& Indah, 2020), (Harti et al., 2017), (Imamah \& Reza, 2014), dan (Sumiyati et al., 2018) diketahui bahwa melalui permainan tebak-tebakan keterampilan berbicara anak meningkat yakni mencakup pelafalan, penambahan kosakata dan pembentukan kaimat. Adapun perbedaan antara penelitian yang akan diteliti dengan keempat penelitian tersebut adalah peneliti disini mencoba untuk melihat bagaimana penerapan permainan bahasa guessing games berbasis powerpoint dalam meningkatkan keterampilan berbicara anak usia dini. Permainan berbasis powerpoint merupakan salah satu metode edukasi yang mampu membangkitkan rasa ketertarian anak dalam proses pembelajaran.

Guessing games berbasis powerpoint ini merupakan game yang dibuat dengan aplikasi pada software Microsoft bernama PowerPoint
Presentation dan game ini dapat memberikan desain yang baik untuk anak agar lebih fokus pada proses pembelajaran. Keunggulan dari permainan ini antara lain memberikan kesempatan untuk meniru suatu kegiatan, menyenangkan untuk dimainkan, mudah dibuat atau diedit dan tidak memerlukan koneksi internet (Barbour \& Siko, 2013, hlm. 89). Permainan berbasis powerpoint memberikan kesempatan bagi anak dalam menghadapi pembelajaran di era informasi. Anak juga mampu bermain permainan dengan instruksi yang baik yang diberikan oleh powerpoint karena variasi desain dan animasi dapat merangsang minat anak dan belajar dengan baik di kelas (Ali et al., 2013, hlm. 4067; Oktaviana et al., 2017, hlm. 29). Berdasarkan dari hal tersebut, maka peneliti berniat untuk meneliti bagaimana penerapan permainan bahasa guessing game berbasis powerpoint dalam meningkatkan keterampilan berbicara anak usia dini, yang diharapkan melalui penelitian ini mampu memberikan tambahan wawasan dalam hal menstimulasi perkembangan bahasa anak khususnya yakni keterampilan berbicara anak.

\section{METODOLOGI PENELITIAN}

Penelitian ini memakai pendekatan kualitatif yang bertabiat deskriptif dengan desain penelitian studi kasus. Peneliti mendeskripsikan tentang penerapan permainan bahasa guessing games berbasis powerpoint dalam meningkatkan keterampilan berbicara pada anak usia dini di Kelompok B Taman Kanak-Kanak Thoyyibah Kota Bandar Lampung.

Sumber informasi dalam pengumpulan data memakai informasi primer serta informasi skunder. Dalam perihal informan riset selaku sumber informasi primer merupakan Kepala Sekolah TK Thoyyibah, guru kelas serta anak Kelompok B. Sedangkan sumber data skunder adalah data-data terkait penerapan permainan bahasa guessing 
games dalam meningkatkan keterampilan berbicara anak usia dini yaitu meliputi: RPPH, alat permainan edukatif berupa permainan bahasa guessing games berbasis powerpoint, serta hasil evaluasi dan lain sebagainya.

Metode pengumpulan data yang digunakan oleh peneliti dalam riset ini merupakan observasi, wawancara serta dokumentasi. Berikutnya, metode analisis data yang periset pakai meliputi data collection, data reduction dan drawing conclusions.

\section{HASIL PENELITIAN DAN PEMBAHASAN}

Bersumber pada hasil riset yang sudah periset jalani di Kelompok B Taman Kanak- kanak Thoyyibah Kota Bandar Lampung diketahui bahwa teknik pendidik mengaplikasikan permainan bahasa guessing games berbasis powerpoint dalam tingkatkan keterampilan berbicara anak usia dini. Namun disini pendidik tidak melakukan pembelajaran di dalam kelas tetapi dialihkan pembelajaran di dalam rumah. Hal tersebut dikarenakan sesuai dengan arahan Presiden Joko Widodo yang menghimbau masyarakat, khususnya di wilayah terkena dampak dari Penyakit Coronavirus (Covid-19) untuk bekerja dari rumah, belajar dan beribadah hingga membatasi interaksi (social distancing) untuk mencegah penyebaran Covid-19. Kemendikbud juga mengimbau para pendidik untuk melakukan kegiatan pembelajaran yang menarik bagi siswa di rumah atau biasa disebut dengan istilah Study From Home (SFH).

Sejalan dengan Mendikbud RI tentang Surat Edaran No. 4 Tahun 2020 tentang pelaksanaan kebijakan pendidikan dalam masa darurat penyebaran Covid-19, pendidik wajib mengusahakan supaya aktivitas belajar mengajar senantiasa berjalan dengan efisien dan efektif, walaupun perserta didik posisi di dalam rumah. Prihal ini dapat diatasi dengan cara mendesain inovasi pembelajaran dalam menggunakan media dalam jaringan (online) (Nurdin \& Anhusadar, 2020, hlm. 687). Dalam hal ini pendidik mengembangkan strategi pembelajaran dengan cara membaginya menjadi beberapa kelompok untuk belajar dari rumah ke rumah dalam setiap pertemuan. Karena jumlah peserta didik dalam satu kelas hanya 12 , maka pembagian dibuat menjadi dua kelompok yang terdiri dari enam peserta didik. Dengan tetap menerapkan social distancing dan selalu menjaga kebersihan, maka yang dilakukan pendidik selama proses kegiatan penerapan permainan bahasa guessing games berbasis powerpoint dalam meningkatkan keterampilan berbicara anak terdiri dari tiga tahap yaitu perencanaan, pelaksanaan yang terdiri dari kegiatan awal, kegiatan inti dan kegiatan akhir, kemudian tahap ketiga yaitu penilaian atau evaluasi keterampilan berbicara anak melalui permainan bahasa guessing games berbasis powerpoint.

Tahap pertama yaitu perencanaan, perencanaan permainan bahasa guessing games berbasis powerpoint di kelompok B diawali dengan menyiapkan rencana dan kegiatan yang dirancang sesuai dengan kurikulum, kurikulum yang digunakan di TK Thoyyibah Kota Bandar Lampung berpedoman pada kurikulum 2013. Merencanakan rencana kegiatan satu tahun, kemudian Menyusun sebuah rencana kegiatan mingguan, kemudian yang terakhir pendidik menyusun RPPH yang telah disesuaikan dengan Permendikbud No. 146 tahun 2014. Selain menyusun desain program dan kegiatan pembelajaran, pendidik juga menyiapkan media permainan bahasa guessing games berbasis powerpoint dengan bantuan proyektor untuk menampilkan keluaran powerpoint pada permukaan datar seperti dinding putih menggunakan kabel HDMI, selain itu proyektor pendidik juga menggunakan speaker aktif untuk memperkuat atau memperjelas keluaran suara dari powepoint, sehingga suara yang 
dihasilkan didengar dengan jelas oleh peserta didik (Sobiruddin et al., 2019, hlm. 13). Dalam penyususnan permainan guessing games berbasis powerpoint, pendidik menyusun dengan menyesuaikan tahapan usia dan kebutuhan anak terhadap media yang akan diterapkan, kemudian pendidik akan mengumpulkan materi yang mendukung dalam pembelajaran seperti mencari materi yaitu teks, video, gambar dan animasi yang sesuai dengan RPPH di waktu itu.

Tahap kedua, pelaksanaan permaianan bahasa guessing games berbasis powerpoint terdiri dari tiga kegiatan yaitu kegiatan awal, sebelum melakukan permainan bahasa guessing games pendidik meminta anak duduk membentuk setengah lingkaran yang kemudian memeriksa kesiapan anak dalam mengikuti pembelajaran sampai akhir kegiatan, setelah anak terlihat siap dan terkondisi pendidik akan menjelaskan materi dengan menampilkan media permainan bahasa guessing games berbasis powerpoint untuk memikat ketertarikan anak-anak supaya anak bisa terpusat pada media. Kegiatan inti, pendidik sebelum menerapkan permainan bahasa guessing games, pendidik selalu memulai dengan bercerita terlebih dahulu, kemudian menghubungkannya dengan kehidupan anak melalui bahasa yang sinkron untuk anak, sehingga anak dapat lebih memahami isi cerita. Setelah bercerita, pendidik menjelaskan langkahlangkah dalam permainan guessing games, antara lain pendidik akan mengajak anak mengamati gambar yang ada di PowerPoint, kemudian anak diminta menebak gambar dengan menghubungkan gambar yang sesuai dengan namanya, mencari gambar yang sama dengan bayangan, menebak warnanya, menebak huruf atau kata yang hilang dalam susunan kalimat dan mengingat kembali kisah kehidupan di dasar laut yang dipelajari anak-anak. Kegiatan terakhir pendidik mengkondisikan anak untuk tenang kembali, Kemudian beri anak kesempatan untuk menceritakan kembali aktivitas tersebut, setelah itu pendidik juga sesekali memberikan pertanyaan sederhana tentang kegiatan permainan bahasa yang telah dilakukan. Baik itu menanyakan perasaan anak selama kegiatan berlangsung. Selanjutnya pendidik menyampaikan pesan-pesan yang terdapat dalam pembelajaran dan mengulasnya kembali.

Hal ini senada dengan yang dikemukakan oleh (Harmer, 2007, hlm. 238) terkait Langkah-langkah permainan bahasa guessing game berbasis powerpoint yaitu dilakukan dengan membentuk kelompok kecil, kemudian guru akan menampilkan sebuah gambar atau susunan kalimat yang dimana masing peserta didik akan menjawab pertanyaan yang di berikan oleh pendidik. Setelah anak menjawab, pendidik akan menanyakan kembali kepada anak apa yang dia tebak. Menurut Klippel yang menjadi aturan dasar guessing games itu sendiri sangatlah sederhana dimana satu orang mengetahui sesuatu yang ingin diketahui oleh orang lain (Klippel, 1994, hlm. 13). Selain itu, (Merriem, 1986, hlm. 1008) mengemukakan dimana dengan bermain guessing games akan memberikan rasa semangat baik itu secara individu maupun berkelompok dalam mengidentifikasi sesuatu. Berdasarkan penjelasan diatas, maka dapat disimpulkan dalam guessing games terdiri dari seseorang yang mengetahui sesuatu yang kemudian secara individu atau berkelompok akan mengidentifikasinya atau menebaknya.

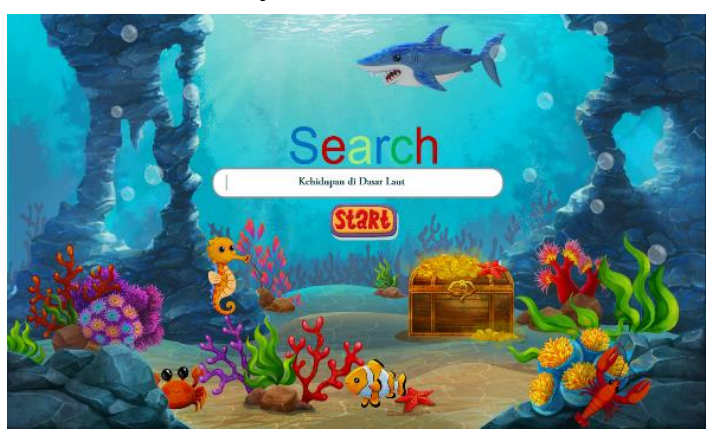


Gambar 1: Tampilan awal permainan berbasis powerpoint.

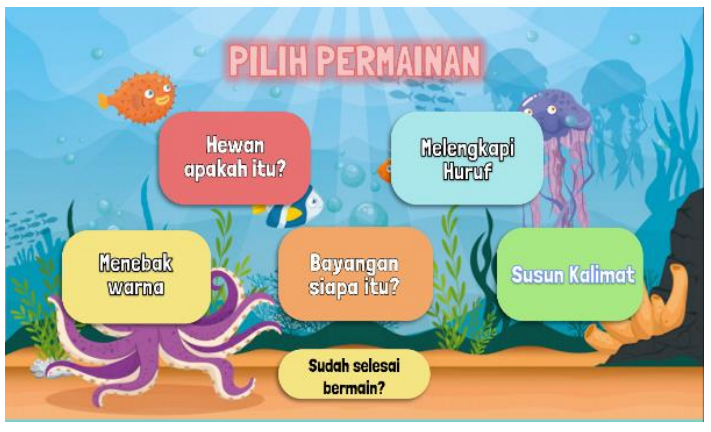

Gambar 2: Menu permainan berbasis powerpoint.

Selanjutnya tahap ketiga yang merupakan tahap terakhir dalam penerapan permainan bahasa guessing games berbasis powerpoint yaitu evaluasi, bersumber pada hasil riset yang sudah periset teliti, pada tahap evaluasi TK Thoyyibah Kota Bandar Lampung mengevaluasi atau menilai pembelajaran meliputi mengevaluasi pelaksanaan pembelajaran dan menilai pencapaian keterampilan berbicara anak. Penilaian dilakukan pada saat kegiatan pembelajaran, dimana pendidik berperan sebagai peneliti terhadao tahap pencapaian kemampuan berbicara anak. Evaluasi pembelajaran biasanya dilakukan di akhir tema. Menurut Suyadi, mengemukakan bahwa penilaian adalah proses pengukuran hasil kegiatan pembelajaran dimana evaluasi dilaksanakan secara urut, ternilai, berkelaluan dan inklusif meliputi aspek perkembangan anak yang telah dicapai dalam suatu pembelajaran (Suyadi, 2016, hlm. 69-70).

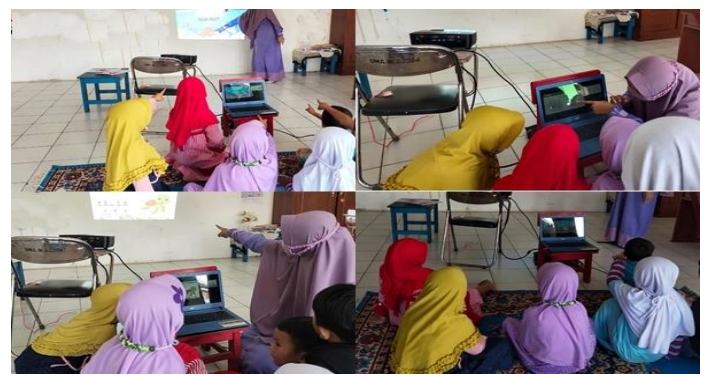

Gambar 3. Kegiatan Permaian Bahasa Guessing Games.
Pada saat kegiatan permainan bahasa guessing games berbasis powerpoint, anak-anak terlihat antusias memperhatikan gambar yang ada pada tampilan powerpoint dan saat guru memberikan umpan kepada anak untuk menebak sebuah gambar terlihat anak dengan semangat menjawab, namun masih terdapat beberapa faktor pendukung serta penghambat dalam pelaksanaan menerapkan permainan bahasa guessing games. Adapun yang menjadi faktor pendukung permainan bahasa guessing games tentunya penyajian media yang berbasis powerpoint menarik perhatian anak sehingga fokus pada materi yang disajikan, kemudian tampilan powerpoint yang telah dibuat pendidik juga sudah menyuguhkan warna-warna serta gambar yang menarik. Pelaksanaan permainan bahasa guessing games pun dilakukan dengan cara yang menyenangkan dan Selain itu juga memberikan reward kepada anak-anak, bertujuan untuk memotivasi mereka dan membuat mereka terus semangat mengikuti cerita. Sedangkan faktor yang membatasi aktivitas pada guessing games adalah terbatasnya fasilitas berupa laptop, sehingga anak tidak dapat langsung menjawab tebakan yang diberikan oleh guru dalam aplikasi PowerPoint, kemudian keingintahuan anak terhadap media tersebut membuat beberapa anak berebut untuk memegang laptop, untuk mengatasi hal tersebut guru menunjukkan media secara bergiliran kepada anak kemudian memberikan pengertian kepada anak untuk kembali ke posisi duduknya dan memperhatikan melalui layar proyektor.

Permainan bahasa guessing games berbasis powerpoint memiliki banyak manfaat, salah satunya yaitu meningkatkan keterampilan berbicara anak yang merupakan bagian dari perkembangan bahasa anak. Keterampilan berbicara perlu diberikan perlakuan yang tepat agar dapat berkembang sesuai 
tahapan usia. Anak dengan kemampuan berbicara yang kuat akan memiliki tingkat kepercayaan diri yang tinggi pada anaknya, yang akan mendorong mereka untuk tumbuh dan berkembang dalam aspek lain. Keadaan ini selaras dengan hasil riset yang diteliti oleh Bonamy dan Leonard, dimana anak-anak yang kurang kompeten dalam berbicara atau berkomunikasi yang tidak sesuai dengan konteks cenderung mengalami permasalahan dalam keterampilan sosialnya. aspek lain dari perkembangan anak (Bonamy, 2016, hlm. 385). Selain menstimulasi anak dalam mengucapkan kata atau menyampaikan pikiran anak, dalam permainan bahasa guessing games berbasis powerpoint ini juga dapat menambah serta membangun kosakata anak. Pemahaman kosakata yang baik tentunya akan mempengaruhi kemampuan berbicara anak. anak akan mengalami kesulitan dalam berkomunikasi dan berinteraksi jika perbendaharaan katanya terbatas (Amini \& Suyadi, 2020, hlm. 125). Oleh karena itu, anak membutuhkan pemahaman kosakata yang cukup dan baik agar lebih banyak informasi yang akan diterima anak atau diberikan kepada orang lain.

Usman berpendapat bahwa kemampuan berbahasa dapat dinilai dari tiga segi, yaitu: bahasa yang dipakai melibatkan lafal, intonasi, pemilihan kata, struktur dan gaya kata; isi dialog, termasuk isi dan isi Hubungan antara struktur, jumlah konten, dan akhirnya; teknik dan penampilan gerak tubuh dan mimik, hubungan dengan penonton, jumlah dan arah dialog (Usman, 2015, hlm. 41). Sementara itu, Hugher mengemukakan bahwa aspek-aspek yang terlibat dalam keterampilan berbicara yaitu: aksen atau tekanan kata, tata bahasa, kosa kata, kelancaran atau kefasihan berbicara serta pemahaman (Usman, 2015, hlm. 40). Selanjutnya, Hurlock menjelaskan bahwa keterampilan berbicara melibatkan tiga aspek, yakni: mengucapkan kata, membangun kosa kata serta membentuk kalimat (Hurlock, 2002, hlm. 85). Berdasarkan hal di atas, keterampilan berbicara dapat dipandang dari pengucapan anak, pengembangan kosa kata serta pembentukkan kalimat.

Usman percaya bahwa tugas utama keterampilan berbicara adalah mempelajari pengucapan. pelafalan dipelajari melalui peniruan, dan anakanak hanya dapat merasakan pengucapan kata-kata orang yang berkomunikasi dengannya. Akurasi pengucapan setiap anak berbeda. Beberapa anak bersandar pada tahap perkembangan sistem suara, lamun mayoritas bergantung pada arahan mereka untuk melibatkan suara dengan kata-kata yang bermakna. Tugas kedua adalah meningkatkan kosakata. Dalam meningkatkan kosakata, anak diharuskan belajar menggabungkan arti dengan suara. Kemudian yang terakhir adalah pembentukan kalimat. Anak usia enam tahun harus bisa menguasai hampir semua struktur kalimat, misalnya panjang kalimat bertambah, dan kalimat biasanya tidak beraturan (Usman, 2015, hlm. 41$55)$.

Berdasarkan hasil penelitian terlihat bahwa pengucapan anak sesuai dengan harapan, anak mulai mengungkapkan keinginannya, anak dapat menebak tebakan yang diberikan oleh pendidik dalam permainan bahasa guessing games. Permainan bahasa guessing games dapat mengembangkan kosakata anak, dimana anak tampak menyebutkan kosakata yang ia peroleh dari gambari-gambar yang tersedia di dalam powerpoint dan juga Ketika anak berkomunikasi dalam kegiatan permainan sudah berkembangan sesuai harapan. Ketika anak bermain permainan bahasa guessing games, tanpa disadari maka perbendaharaan kata anak akan meningkat, disinilah anak menggabungkan kosakata baru dengan kosakata yang sudah dimilikinya dalam proses pembelajaran. Tergantung usianya, anak dengan usia rata-rata 5-6 tahun dapat menggunakan 4-5 kata berupa pernyataan, tanya jawab atau perintah dalam sebuah 
kalimat. (Rahmawati et al., 2017, hlm. 78). Pada akhir kegiatan anak terlihat bahwa kemampuan anak dalam membentuk kalimat sederhana sesuai dengan harapan, hal ini tampat ketika anak jeli menggambarkan kegiatannya yang telah selesai dan mengutarakan pendapatnya. Namun demikian, masih terdapat sebagian anak yang belum mengembangkan keterampilan berbicaranya, karena anak masih malu dalam mengungkapkan bahasanya. Untuk mengatasi masalah tersebut, pendidik berusaha membujuk anak untuk menjawab walaupun dalam keadaan duduk dan bersuara rendah, namun dari segi pengucapan, perkembangan kosa kata dan pembentukan kalimat sudah mulai berkembang dengan baik.

Menurut Usman sendiri, konsep dan ide tidak dapat dikomunikasikan secara langsung dan berbicara mungkin merupakan cara penyampaian yang logis dan canggih dibandingkan dengan cara lain. Pertama anak akan berpikir dan kemudian akan mengungkapkan pemikiran yang ingin disampaikan anak kepada pendengar melalui kata-kata yang mewakili pemikirannya dalam versi anak. Selama masa kanak-kanak, keterampilan berbicara yang dialami anak termasuk menambah kosakata umum (Usman, 2015, hlm. 30). Menurut Pusari, bahasa dan pemikiran anak pada umumnya berlainan. Selanjutnya sinkron dengan fase perkembangan psikologisnya, bahasa dan pemikirannya berpadu, hingga bahasa menjadi ekspresi pemikirannya. Anakanak yang secara alamiah belajar berbicara dari interaksi melalui orang lain, yaitu mengungkapkan pemikiannya dan keinginannya untuk mengerti pola pikir dan kemauan orang lain. Keterampilan berbicara anak dapat dilatihkan dengan berkomunikasi dalam lingkungan bermain kolektif, biasanya anak berkomunikasi dengan teman secara otomatis saat bermain bersama (Pusari, 2016, hlm. 65).

Permainan bahasa adalah sesuatu yang menyenangkan dan anak-anak suka bermain. Inti dari permainan bahasa adalah membuat anak belajar bahasa dalam kondisi yang menyenangkan. Menurut Lewis and Bedson mengemukakan bahwa, melalui bermain, anak dapat mengekspresikan dirinya dengan menemukan berbagai hal dan berinteraksi dengan lingkungan. Dengan tidak memasukkan game ke dalam kelas, berarti pendidik memotong kesempatan anak untuk memahami dunia mereka (Usman, 2015, hlm. 92). Permainan bahasa guessing games dapat merangsang keinginan anak untuk berbicara sesuai tebakan dan jawaban, sehingga anak dapat melafalkan dengan baik dan membekali mereka dengan pengalaman dan pengetahuan. Hal ini sesuai dengan ungkapan Harti dkk bahwa bermain merupakan kegiatan yang dirancang untuk memungkinkan anak meningkatkan kemampuan atau keterampilan tertentu berdasarkan pengalaman belajarnya (Harti et al., 2017, hlm. 124).

Pemanfaatan permainan berbasis powerpoint memiliki banyak kelebihan, termasuk penyajian materi yang menarik perhatian anak karena mengandung kombinasi huruf, warna dan animasi yang unik serta membantu anak memberikan pemahaman selama proses pembelajaran. Namun dibalik kelebihan tersebut tentunya terdapat kelemahan yaitu kelemahan penggunaan game berbasis powerpoint yaitu membutuhkan tenaga pendidik yang memiliki keahlian dalam mendesain powerpoint sehingga dapat menghasilkan output yang menarik serta membutuhkan sarana dan prasarana yang memadai. (Karlina et al., 2018, hlm. 25). Rusman sendiri mengemukakan bahwa teknologi dapat mempromosikan pembelajaran serta pengembangan yang efektif pada anak ketika teknologi dapat dimanfaatkan secara baik dan tepat oleh para pendidik (Rusman, 2018, hlm. 147154). Aplikasi yang terdapat di dalam komputer yang merupakan media pembelajaran interaktif diharapkan dapat memberikan kemudahan bagi pengguna 
khususnya pada anak sehingga anak dapat belajar sambil bermain secara menyenangkan melalui komputer. Permainan guessing games berbasis powerpoint dapat merangsang keterampilan berbicara anak usia dini sehingga esensi atau pengetahuan yang diperoleh dapat digunakan untuk memecahkan masalah dalam proses stimulasi.

Berdasarkan hal tersebut, penerapan permainan bahasa guessing games berbasis powerpoint merupakan hal yang tepat dalam merangsang keterampilan berbicara anak usia dini. Karena anak sangat suka bermain permainan, melalui permainan ini anak menjadi lebih mudah memahami informasi yang ingin diungkapkan kepada pendidik. Selain itu, melalui permainan guessing games ini, anak-anak akan secara aktif mengekspresikan kosa kata mereka saat mengungkapkan pikiran dan emosi. Reaksi anak dalam proses pembelajaran seperti antusiasme anak dalam menjawab tebakan pendidik membuktikan hal tersebut.

\section{KESIMPULAN}

Keterampilan berbicara anak dapat distimulasi dan dikembangkan dengan baik dan siginifikan melalui penerapan permainan bahasa guessing games berbasis powerpoint. Bersumber pada hasil riset yang sudah periset lakukan pada Kelompok B di Taman Kanak-Kanak Thoyyibah Kota Bandar Lampung terkait proses kegiatan pembelajaran dengan penerapan permainan bahasa guessing games berbasis powerpoint dalam meningkatkan keterampilan berbicara anak usia dini sudah berjalan dengan cukup baik, adapun proses terdiri dari tiga tahapan, yakni: tahap perencanaan, tahap pelaksanaan yang meliputi kegiatan awal, kegiatan inti dan kegiatan akhir, kemudian tahap evaluasi atau penilaian.

Tahap perencanaan dimulai dengan penyusunan RPPH terlebih dahlulu dan media permainan bahasa guessing games berbasis powerpoint serta alat-alat pendukung lainnya (proyektor dan speaker aktif). Kemudian tahap pelaksanaan, dalaam kegiatan awal pendidik terlebih dahulu mengkondisikan anak sehingga anak siap berpartisipasi dalam kegiatan, selanjutnya kegitan inti pembelajaran dengan penerapan permainan bahasa guessing games berbasis powerpoint, pendidik mengikuti prosedur dalam permainan guessing games dintaranya yaitu: pendidik membagi peserta didik menjadi dua kelompok kecil, kemudian pendidik baru akan menjelaskan materi yang terkait yang didalamnya diselingi oleh permainan guessing games, pendidik mengajak anak untuk menebak sebuah gambar atau huruf yang hilang dan saat itu anak-anak terlihat antusias dalam menyimak dan juga menebak setiap hal yang mereka lihat dan kemudia yaitu kegiatan, guru akan mengulas kembali kegiatan yang telah dilakukan. Dalam tindakan ini tampak anak didik bersunguh - sungguh dalam mengemukakan pikiran mereka terkait kegiatan dan juga menjawab pertanyaanpertanyaan yang diberikan oleh pendidik. Pada tahap akhir yaitu evaluasi atau penilaian, biasanya dilakukan pada setiap akhir tema. Adapun yang menjadi faktor pendukung permainan bahasa guessing games tentunya penyajian media yang berbasis powerpoint menarik perhatian anak sehingga fokus pada materi yang disajikan. Sedangkan faktor yang menjadi penghambat kegiatan permainan bahasa guessing games adalah keterbatasanya sarana sehingga membuat beberapa anak berebutan melihat media, untuk mengatasinya guru memperlihatkan media secara bergilir kepada anak setelah itu memberikan pengertian kepada anak untuk kembali pada posisi duduknya dan memperhatikan melalui layar proyektor.

\section{DAFTAR PUSTAKA}

Ali, G., Haolader, F. A., \& Muhammad, K. (2013). The Role of ICT to Make Teaching Learning Effective in 
Higher Institutions of Learning in Uganda. International Journal of Innovative Research in Science, Engineering and Technology, 2(8), 4061-4073.

Amini, N., \& Suyadi, S. (2020). Media Kartu Kata Bergambar Dalam Meningkatkan Kemampuan Kosakata Anak Usia Dini. PAUDIA : Jurnal Penelitian dalam Bidang Pendidikan Anak Usia Dini, 9(2), 125.

Ayuandia, N., Saparahayuningsih, S., \& Ardina, M. (2017). Meningkatkan Keterampilan Berbicara Melalui Metode Karyawisata Pada Anak Kelompok B Lab School PAUD UNIB Kota Bengkulu. Jurnal Ilmiah Potensia, 2(1), 33-38.

Barbour, M. K., \& Siko, J. P. (2013). Game Design and Homemade Power Point Games: An Examination of The Justifications and A Review of The Research. Journal of Educational Multimedia and Hypermedia, 22(1), 81-108.

Bonamy, R. (2016). Social Cognition And Conduct Problems a Development Approach. Journal of the American of Child and Adolescent Psychiatry, 50(4), 385-994.

Budiarti, \& Indah, S. N. (2020). Penerapan Permainan Tebak Gambar dan Huruf untuk Meningkatkan Kemampuan Berbahasa Anak Kelompok A1 TK Negeri Pakunden 1 Kota Blitar. jurnal Pendidikan: Riset dan Konseptual, 4(2), 285-292.

Dhear, A., Cahyani, N., \& Rasydah, A. (2020). Upaya Meningkatkan Minat Membaca Anak Usia 4-5 Tahun Yang Berkorelasi Dengan Tri Pusat Pendidikan. Cakrawala Dini : Jurnal Pendidikan Anak Usia Dini, 11(2), 115.

Harmer, J. (2007). The Practice of English Language Teaching. Pearson Education.

Harti, M. B., Sumarsih, S., \& Suprapti, A. (2017). Penerapan Permainan Tebak
Kata Untuk Meningkatkan Keterampilan Berbicara Anak (Penelitian Tindakan Kelas di Kelompok B PAUD Lestari Bengkulu Tengah). Jurnal Ilmiah Potensia, 2(2), 121-125.

Hasanah, U. (2019). Penggunaan Alat Permainan Edukatif (APE) Pada Taman Kanak-Kanak di Kota Metro Lampung. Awlady: Jurnal Pendiidkan Anak, 5(1), 20-40.

Hurlock, E. B. (2002). Perkembangan Anak Jilid 1. Erlangga.

Imamah, N. R., \& Reza, M. (2014). Pengembangan Permainan Tebak Kata Modifikasi Untuk Meningkatkan Kemampuan Bahasa Lisan Anak Usia Dini Kelompok B Di Taman Kanak-Kanak. Jurnal PAUD Teratai, 3(3), 1-7.

Karlina, I., Kurniah, N., \& Ardina, M. (2018). Media Berbasis Information and Communication Technology (ICT) dalam Pembelajaran Sains Pada Anak Usia Dini. Jurnal Ilmiah Potensia, 3(2), 25.

Klippel, F. (1994). Keep Talking. Cambridge University Press.

Kurnia, R. (2019). Bahasa Anak Usia Dini. Deepublish Publisher.

Kurnia, R., \& Solfiah, Y. (2018). Pengaruh Media Pensil Karakter Animasi Upin dan Ipin Terhadap Kemampuan Menulis Anak. Jurnal Obsesi: Jurnal Pendidikan Anak Usia Dini, 12(2), 344.

McCoy, D. C., Yoshikawa, H., M.ZiolGuest, K., Duncan, G. J., Schindler, H. S., Magnuson, K., Yang, R., Koepp, A., \& Shonkoff, J. P. (2017). Impacts of Early Childhood Education on Medium-and Longterm Educational Outcomes. Educational Researcher, 46(8), 474487.

Merriem, W. (1986). Webster's Third New International Dictionary. Merriem Webster inc.

Nestor, O., \& Mose, C. S. (2018). The Importance of Play. Journal of 
Occupational Therapy, Schools, \& Early Intervention, 11(3), 247-262.

Nurdin, \& Anhusadar, L. (2020).

Efektivitas Pembelajaran Online

Pendidik PAUD di Tengah Pandemi

Covid 19. Jurnal Obsesi: Jurnal

Pendidikan Anak Usia Dini, 5(1), 687.

Nurzaman, I., Gandana, G., \& Wahidah, A. S. (2020). Model Pembelajaran Interactive Storytelling Berbasis Aplikasi Android Untuk Memfasilitasi Keterampilan Menyimak Anak Usia Dini. Cakrawala Dini : Jurnal Pendidikan Anak Usia Dini, 11(2), 135.

Oktaviana, S., Santoso, B., \& Hiltrimartin, C. (2017). Penggunaan Power Point Game pada Pembelajaran Lingkaran di Kelas VIII SMP Negeri 1 Tanjung Raya. Jurnal Pendidikan Matematika, 11(1), 29-42.

Pusari, R. W. (2016). Analisis Pemanfaatan Alat Permainan Edukatif (Ape) Dalam Menciptakan Pembelajaran Bahasa Di Tk Tunas Rimba Ii Kota Semarang. Malih Peddas (Majalah Ilmiah Pendidikan Dasar), 6(1), 65. https://doi.org/1118 Puspita, A. C., Perbawani, A. A., Adriyanti, N. D., \& Sumarlam. (2019). Analisis Bahasa Lisan Pada Anak Keterlambatan Bicara (Speech Delay) Usia 5 Tahun. Lingua: Jurnal Bahasa, Sasyta dan Pengajarannya, 15(2), 154-160.

Rahmawati, D., Riswandi, \& Surahman, M. (2017). Peningkatan Keterampilan Berbicara Anak Usia Dini Melalui Metode Bercerita. Jurnal Pendidikan Anak, 3(2), 7-8.

Ruiyat, S. A., Yufiarti, \& Karnadi. (2019). Peningkatan Keterampilan Berbicara dengan Bercerita Menggunakan Komik Elektronik Tematik. Jurnal Obsesi: Jurnal Pendidikan Anak Usia Dini, 3(2), 519.

Rusman. (2018). Belajar dan Pembelajaran Berbasis Komputer Mengembangkan Profesionalisme
Guru Abad 21. Alfabeta.

Shofa, M. F., \& Suparno, S. (2014). Peningkatan Keterampilan Berbicara Anak Usia Dini Melalui Permainan Sandiwara Boneka. Jurnal Pendidikan dan Pemberdayaan Masyarakat, 1(2), 211.

Singer-Brodowski, M., Brock, A., Etzkom, N., \& Otte, I. (2019). Monitoring of Education for Sustainable Development in Germany-Insights From Early Childhood Education, School and Higher Education. Environmental Education Research, 25(4), 492507.

Siregar, A. O., \& Hazizah, N. (2019). Studi Kasus Keterlambatan Bicara Anak Usia 6 Tahun di Taman KanakKanak. Aulad: Journal on Early Childhood, 2(2), 22-27.

Sobiruddin, D., Dwirahayu, G., \& Kustiawati, D. (2019). Pengembangan Media Ict Berbasis Proyektor Interaktif Bagi Guru Dan Siswa Raudhathul Athfal (Ra). Edcomtech Jurnal Kajian Teknologi Pendidikan, 4(1), 13.

Sumiyati., Supriyati., \& Subawi. (2018). Peningkatan Kemampuan Berbahasa Anak Melalui Permainan Tebak Nama. Golden Age: Jurnal Ilmiah Tumbuh Kembang Anak Usia Dini, 3(2), 131-140.

Suyadi, S. (2016). Perencanaan dan Asesmen Perkembangan Pada Anak Usia Dini (Studi kasus pada Lembaga Pendidikan Anak Usia Dini (PAUD/TK/RA) di Daerah Istimewa Yogyakarta). Golden Age: Jurnal Ilmiah Tumbuh Kembang Anak Usia Dini, 1(1), 70-71.

Syarif, M. A. (2016). Peningkatan Kemampuan Bahasa Anak Usia Dini Melalui Karyawisata. Awlady: Jurnal Pendidikan Anak, 2(2), 1-11.

Taufiqurrahman, S., \& Suyadi. (2016). Analisi Aspek Perkembangan Bahasa Anak Dasar Dalam Proses Pembelajaran. PIONIR: Jurnal 
Pendidikan, 8(2), 160.

Triyaningsih. (2016). Improving of Speaking Ability Early Childhood Age 5-6 Years Through Playing Role in Tk Anak Bangsa Ciomas Bogor. Journal of Guidena and Counseling, 6(1), 18.

Usman, M. (2015). Perkembangan Bahasa dalam Bermain dan Permainan : Untuk Pendidikan Anak Usia Dini. Deepublish Publisher.

Wasik, B. A., \& Jacobi-Vessels, J. L. (2017). Word Play: Scaffolding Language Development Through Child-Directed Play. Early Childhood Education Journal, 45(6), 769-776. 